\title{
Pendampingan Orang Tua Siswa Melalui Penyusunan Media Alat Hitung Manual (ALHIMA) dalam Mendampingi Anak Belajar dari Rumah Selama Masa Pandemi Covid-19
}

\author{
Silviana Nur Faizah, Ummu Khairiyah, Winarto Eka Wahyudi, Mudzaki Risma \\ Fakultas Agama Islam, Universitas Islam Lamongan \\ E-mail: ekawahyudi1926@unisla.ac.id
}

\begin{tabular}{ll}
\hline Article History: & Abstract: The implementation of online learning \\
Received: July $12^{\text {th }} 2020$ & under the Minister of Education and Culture Circular \\
Revised: Aug $16^{\text {th }} 2020$ & No. 4 of 2020 during the Covid-19 pandemic caused \\
Accepted: Nov $30^{\text {th }} 2020$ & new problems. $76 \%$ of 25 parents in grade I primary \\
& schools in Sugihrejo village had difficulty assisting \\
& children in learning numeracy material. Training on \\
Keywords: manual counting & the preparation of manual counting media \\
media, parent learning & (ALHIMA) is an absolute effort to improve the \\
assistance, service learning. & quality of parent learning assistance on numeracy \\
& material. By using the service-learning method, this \\
& service is proven to be able to improve the quality of \\
& parent learning assistance on numeracy material \\
& which is characterized by new skills that parents \\
have, including knowing the importance of using \\
learning media, mastering the concept of addition \\
and subtraction, using ALHIMA media for assistance \\
in learning counting material, and being aware of \\
the importance of providing the best assistance for \\
children's academic success.
\end{tabular}

\section{Pendahuluan}

Rendahnya mutu di dunia pendidikan Indonesia merupakan masalah krusial yang hingga saat ini masih menjadi pekerjaan rumah (PR) bagi bangsa dalam mengatasinya. Menurut Husaini Usman dalam Umiarso terdapat tiga factor rendahnya mutu pendidikan di Indonesia. Pertama, kebijakan dan penyelenggaraan pendidikan nasional menggunakan pendekatan educational production function atau input-input analisis yang tidak konsisten. Kedua, penyelenggaraan pendidikan dilakukan secara sentralistis. Ketiga, peran-serta masyarakat khususnya orang tua siswa dalam penyelenggaraan pendidikan sangat minim ${ }^{1}$

Peran-serta masyarakat khususnya orang tua di era pandemi Covid-19 menjadi

1 Umiarso dan Imam Gojali, Manajemen Mutu Sekolah Di Era Otonomi Pendidikan (Jogjakarta: IRCiSod, 2011). 
kunci pelaksana pembelajaran setelah terbit Surat Edaran Nomor 4 Tahun 2020 yang menyatakan bahwa proses pembelajaran dilaksanakan secara daring atau dari rumah dengan tujuan pengalaman belajar yang bermakna bagi siswa, tanpa terbebani tuntutan menuntaskan seluruh capaian kurikulum untuk kenaikan kelas maupun kelulusan. ${ }^{2}$ Adanya pandemic Covid-19 ini mengubah budaya belajar siswa di sekolah sebagai tanggungjawab guru berpindah ke budaya belajar dari rumah yang sepenuhnya menjadi tanggung jawab orang tua dimana peran orang tua sebagai pengganti guru dirumah dalam membimbing anaknya selama proses pembelajaran. ${ }^{3}$

Bagi pendidik Covid-19 merupakan sebuah tantangan dan transformasi klasik, dimana tidak ada rancangan pedoman sebelumnya, sehingga sampai saat ini belum ada pedoman pembelajaran yang sesuai dengan kondisi yang ada. ${ }^{4}$ Berbagai upaya telah dilakukan pendidik satu diantaranya adalah melakukan pembelajaran online secara keseluruhan maupun menggunakan metode konvensional seperti menggunakan buku teks kemudian metode pengumpulan tugas melalui web. ${ }^{5}$ Hal serupa juga dilakukan oleh pendidik di SDN Sugihrejo I dan SDN Sugihrejo II yang menggunakan pembelajaran konvensional berbasis internet misalnya seperti yang dilakukan oleh guru di Kelas I dalam mengajarkan materi berhitung, guru membuat video tutorial penjumlahan dan pengurangan, kemudian saat jam pelajaran dimulai siswa diberi waktu untuk menyimak video yang diberikan oleh guru dan selanjutnya siswa diberi tugas untuk dikerjakan dengan waktu yang telah ditentukan. Adapun hasil pekerjaan siswa kemudian di foto dan dikirim via whatsapp group sebagaimana gambar berikut.

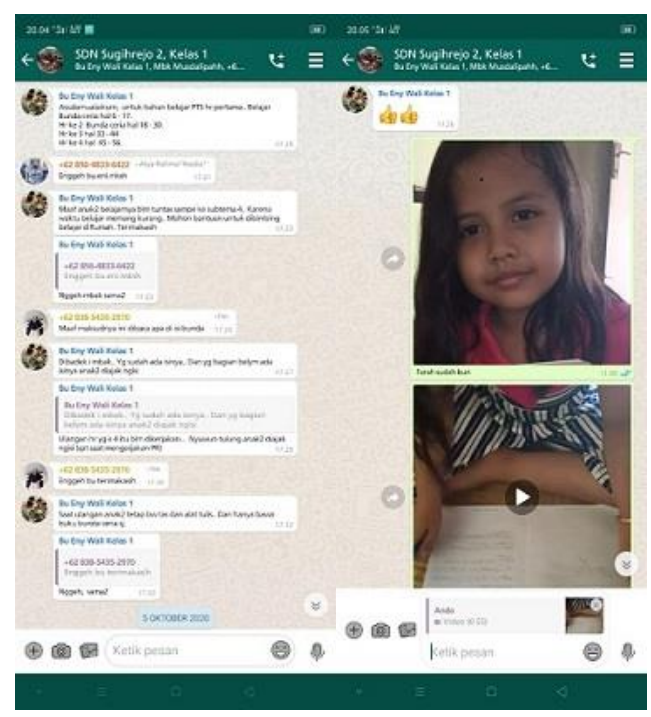

2 Menteri Pendidikan dan Kebudayaan Republik Indonesia, Pelaksanaan Kebijakan Pendidikan dalam Masa Darurat Penyebaran Corona Virus Desease (COVID-19) (Indonesia, 2020).

${ }^{3}$ Nika Cahyati and Rita Kusumah, "Peran Orang Tua Dalam Menerapkan Pembelajaran Di Rumah Saat Pandemi Covid 19," Jurnal Golden Age, Universitas Hamzanwadi 04, no. 1 (2020): 4-6.

${ }^{4}$ Fernando Reimers et al., "Supporting the Continuation of Teaching and Learning during the COVID-19 Pandemic" (2020): 1-38.

${ }^{5}$ Henny Yulia, "Online Learning to Prevent the Spread of Pandemic Corona Virus in Indonesia," ETERNAL (English Teaching Journal) 11, no. 1 (2020): 48-56. 
Gambar 1. Foto Kegiatan Pembelajaran via Whatsapp di SDN Sugihrejo 2

Selama pembelajaran daring berlangsung partisipasi dan keterlibatan orang tua memberikan dampak positif. Hal ini sesuai dengan hasil penelitian yang dilakukan oleh Sheldon yang mengungkapkan bahwa "that successful students' have strong academic support from their involved parents" yaitu siswa yang berhasil memiliki dukungan akademis yang kuat dari orang tua mereka. ${ }^{6}$ Dukungan tersebut dapat berupa pola asuh yang tepat sesuai dengan kebutuhan anak. ${ }^{7}$ Konsep keterlibatan orang tua dalam pembelajaran daring sejalan dengan konsep Manajemen Peningkatan Mutu Berbasis Sekolah (MPMBS) yang merupakan model manajemen yang memberikan otonomi lebih besar kepada sekolah dan mendorong pengambilan keputusan partisipatif yang melibatkan secara langsung semua warga sekolah (guru, siswa, kepala sekolah, karyawan, orang tua siswa, dan masyarakat) untuk meningkatkan mutu sekolah berdasarkan kebijakan pendidikan nasional. ${ }^{8}$

Dengan adanya pandemic covid-19 menciptakan kesadaran terhadap tanggungjawab mendidik dan membina anak secara kontinu9. Adapun tanggungjawab pendidikan yang perlu disadarkan dan dibina oleh orang tua terhadap anak antara lain: (1) memelihara dan membesarkannya, orang tua bertanggungjawab terhadap kebutuhan primer anak seperti makan dan minum supaya anak dapat hidup berkelanjutan; (2) melindungi dan menjamin kesehatannya, baik secara jasmani maupun rohani dari berbagai penyakit maupun segala tindakan maupun keadaan yang dapat mebahayakan anak; (3) mendidiknya dengan berbagai ilmu pengetahuan dan keterampilan sebagai bekal kehidupannya, sehingga anak dapat berdiri sendiri maupun membantu oranglain saat dewasa nanti; (4) membahagiakan anak untuk dunia akhirat dengan memberikan pendidikan agama sesuai ketentuan Allah sebagai akhir hidup muslim. ${ }^{10}$

Empat tanggungjawab orang tua tersebut belum sepenuhnya dilakukan oleh orang tua sebelum adanya pandemi covid-19. Di Desa Sugihrejo para orang tua sepenuhnya mempercayakan pendidikan anak pada sekolah baik sekolah formal maupun non formal. Kehadiran covid-19 memberikan kesadaran akan pentingnya sinergi anatara orang tua dan sekolah di Desa Sugihrejo. Karena itu, perlu adanya proses pendidikan orang tua (education parenting) sebagai bentuk program kerjasama nyata antara orang

${ }^{6}$ Maša Đurišić and Mila Bunijevac, "Parental Involvement as a Important Factor for Successful Education," Center for Educational Policy Studies Journal 7, no. 3 (2017): 137-153.

7 Ade Sadikin Akhyadi and Dinno Mulyono, "Program Parenting dalam Meningkatkan Kualitas Pendidikan Keluarga (Program Pengabdian Di Desa Karangpakuan, Kecamatan Darmaraja, Kabupaten Sumedang)," Abdimas, IKIP SILIWANGI 1, no. 1 (2018): 1-8.

${ }^{8}$ Mulyasa, Manajemen Dan Kepemimpinan Kepala Sekolah (Jakarta: Grafika Offset, 2011).

9 Muh Barid Nizarudin Wajdi et al., "Education Policy Overcome Coronavirus, A Study of Indonesians," EDUTEC: Journal of Education And Technology 3, no. 2 (2020): 96-106.

${ }^{10}$ Mgs Nazarudin, "Pola Kerjasama Guru Dan Orang Tua Dalam Meningkatkan Mutu Pendidikan Di MIN 2 Kota Palembang," Intizar 24, no. 2 (2018): 9-16; Abdul Rasyid Tolangara and Rohima Wahyu Ningrum, "Pendampingan Komunitas Sekolah Melalui Kegiatan Vertical Garden Untuk Mewujudkan Sekolah Dasar Berbasis Lingkungan Di SDN 34 Kota Ternate Maluku Utara," Engagement: Jurnal Pengabdian Kepada Masyarakat 2, no. 1 (2018): 62-70. 
tua dan sekolah. Adapun tujuan education parenting antara lain sebagai berikut: (1) Meningkatkan kesadaran orang tua supaya memberikan pengasuhan terbaik bagi anaknya; (2) Meningkatkan pengetahuan dan keterampilan orang tua dalam hal pengasuhan sesuai dengan karakter, usia, dan perkembangan anak; dan (3) Mempertemukan kepentingan dan keinginan antara keluarga dan pihak sekolah. ${ }^{11}$

Pentingnya education parenting juga dirasakan para orang tua siswa kelas I di Desa Sugihrejo. Berdasarkan hasil angket, 100\% dari 25 orang tua membutuhkan pelatihan untuk mendampingi anak dalam belajar berhitung. Dalam hal ini menurut Smith, Perou \& Lesesne Sebagian orang tua menyadari bahwa mereka berperan penting dalam keberhasilan akademis anak akan tetapi tidak banyak diantara mereka yang mengetahui cara tepat untuk melibatkan diri dalam keberhasilan akademis anak, terutama bagi orang tua yang memiliki latar belakang pendidikan maupun penghasilan yang rendah. ${ }^{12}$

Salah satu langkah konkrit yang dapat dilakukan untuk mengatasi masalah tersebut yaitu dengan memberikan pendampingan penyusunan alat hitung manual kepada orang tua di desa sugihrejo. Tujuan utama dilakukannya pendampingan penyusunan alat hitung manual kepada orang tua di desa sugihrejo adalah memperbaiki kualitas pendampingan belajar orang tua pada materi berhitung sehingga siswa kelas I di desa Sugihrejo dapat dikatakan tuntas berhitung. Selain itu, orang tua perlu teredukasi akan pentingnya tuntas berhitung sebagaimana ditegaskan Nevid dan dan Beverly dalam Aryanti bahwa prestasi siswa di sekolah dapat dipengaruhi oleh perkembangan dalam kemampuan berhitung, membaca, dan menulis. Anak yang memiliki hambatan dalam kemampuan tersebut cenderung memiliki prestasi buruk di sekolannya. ${ }^{13}$

\section{Metode}

Program pendampingan ini menggunakan metode service learning. Menurut Burnet service-learning merupakan metode untuk memperkenalkan konsep-konsep seperti kesadaran budaya, kepekaan, pengetahuan dan keterampilan (bahan untuk kompetensi multikultural) kepada mahasiswa yang memungkinkan mereka terjun langsung ke kelompok budaya yang beragam. ${ }^{14}$ Service learning merupakan pendekatan dalam pengajaran yang menggabungkan tujuan akademik dan upaya menumbuhkan

11 Heri Setiawan, “Peran Orang Tua Dalam Pembelajaran Daring," Suara Merdeka (Indonesia, 2020).

12 Sari Zakiah Akmal, Tjut Rifameutia Ali-nafis, and Patricia Adam, "Efektifitas Program Pelatihan Orang Tua Untuk Meningkatkan Motivasi Menulis Pada Siswa Lambat Belajar," Jurnal Psikogenesis 2, no. 1 (2013): 1-13.

${ }^{13}$ Ariyanti Ariyanti and Zidni Muslimin, "Efektivitas Alat Permainan Edukatif (APE) Berbasis Media Dalam Meningkatkan Kemampuan Berhitung Pada Anak Kelas 2 Di SDN 2 Wonotirto Bulu Temanggung," Jurnal Psikologi Tabularasa 10, no. 1 (2015): 58-69.

14 Helen Dunbar-Krige Venessa Damons, "The Use of Reflection in a Service-Learning Project in a Post-Graduate Programme," Journal of Service-Learning in Higher Education 53, no. 9 (2019): 1689-1699. 
kesadaran dalam memecahkan persoalan masyarakat secara langsung. ${ }^{15}$ Metode service learning ini dilakukan dalam rangka mengkonstruksi makna dari kombinasi antara pengalaman dan studi akademik mahasiswa melalui kegiatan refleksi kritis. ${ }^{16}$ Metode service learning terdiri dari 3 tahap, yaitu tahap persiapan, tahap pelayanan, dan tahap refleksi.

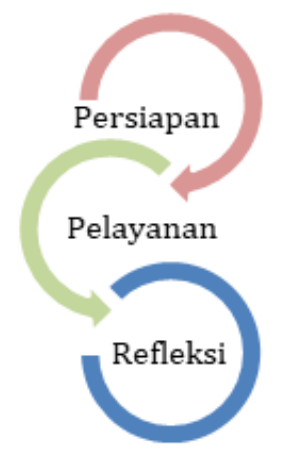

Gambar 2. Tahapan Service Learning Hasil Modifikasi tim PKM17

Tahap persiapan dilakukan dengan memetaan permasalahan yang dihadapi oleh orang tua siswa kelas I SD di desa Sugihrejo dalam mendampingi belajar selama pelaksanaan pembelajaran daring. Pemetaan permasalahan dilakukan dengan cara mengorganisasikan seluruh orang tua siswa kelas I di SDN Sugihrejo I dan SDN Sugihrejo II dalam rangka evaluasi terhadap pembelajaran daring dengan memberikan angket tentang pelaksanaan pendampingan belajar berhitung. Selanjutnya tim PKM melakukan analisis kebutuhan melalui diskusi dengan orang tua terkait kesulitan orang tua dalam mendampingi belajar siswa pada materi berhitung. Adapun kesimpulan dari hasil diskusi adalah orang tua kelas I di Desa Sugihrejo membutuhkan pendampingan terkait penyusunan media alat hitung manual sebagai media dalam mendampingi anak belajar berhitung selama pembelajaran daring. Selanjutnya tim PKM melakukan diskusi dengan guru kelas I dan kepala sekolah di SDN Sugihrejo I dan SDN Sugihrejo II untuk memberikan masukan terhadap pelaksanaan pendampingab penyusunan alat hitung manual kepada orang tua dalam rangka meningkatkan kualitas pendampingan belajar.

Selanjutnya setelah dilakukan diskusi dengan orang tua terkait pelaksanaan pendampingan penyusunan media alat hitung manual memperoleh kesepakatan bahwa, pada tahap pelayanan pendampingan di masa pandemic covid-19 terhadap 25 orang tua

15 Endah Setyowati and Alviani Permata, "Service Learning: Mengintegrasikan Tujuan Akademik Dan Pendidikan Karakter Peserta Didik Melalui Pengabdian Kepada Masyarakat," Bakti Budaya 1, no. 2 (2018): 143.

16 St. Syamsudduha St. Syamsudduha and Nurjannah Yunus Tekeng, "Penerapan Service Learning Dalam Pembelajaran Matakuliah Pedagogik Pada Kurikulum Pendidikan Calon Guru," Lentera Pendidikan : Jurnal Ilmu Tarbiyah dan Keguruan 20, no. 1 (2017): 1-17.

17 Muh Barid Nizarudin Wajdi et al., "Pendampingan Redesign Pembelajaran Masa Pandemi Covid19 Bagi Tenaga Pendidik Di Lembaga Pendidikan Berbasis Pesantren Di Jawa Timur," Engagement: Jurnal Pengabdian Kepada Masyarakat 4, no. 1 (2020): 266-277. 
siswa kelas I desa Sugihrejo dilakukan secara tatap muka dengan membagi menjadi 5 kelompok yang terdiri dari 5 orang tua. Adapun kegiatan pendampingan terdiri dari tiga kegiatan yaitu: (1) sosialisasi urgensi penggunaan media alat hitung manual; (2) pembuatan media alat hitung manual; dan (3) praktik penggunaan media alat hitung manual.

Tahap refleksi merupakan tahap terakhir dalam program pendampingan yang terdiri dari kegiatan evaluasi terhadap pelaksanaan pendampingan. Pada tahap ini orang tua diwajibkan telah memberikan pendampngan belajar kepada anak dengan menggunakan media alat hitung manual. Hasil evaluasi pendampingan diperoleh melalui angket yang telah diberikan kepada orang tua siswa.

\section{Hasil}

Pandemic covid-19 yang terjadi di Indonesia memberikan dampak yang signifikan terhadap tatanan pendidikan, khususnya pada proses pembelajaran. Budaya belajar mulai bergeser dari tatap muka menjadi online sesuai dengan surat edaran menteri pendidikan dan kebudayaan nomor 4 tahun 2020 yang menghimbau untuk belajar dari rumah melalui pembelajaran daring. Pembelajaran daring di Desa Sugihrejo merupakan hal baru bagi siswa di SDN Sugihrejo I dan II. Akibatnya pada pelaksanaannya, pembelajaran daring menuai permasalahan di kalangan orang tua siswa khususnya siswa kelas I SD. Kelas I SD merupakan peralihan dari kebiasaan bermain di Taman Kanakkanak (TK) ke Sekolah Dasar (SD), pada usia ini siswa masuk dala kategori praoperasional konkrit. Menurut piaget siswa sekolah dasar berada pada tahap perkembangan operasional konkrit (umur 7/8 - 11/12 tahun) memiliki ciri berikut: (a) dapat menggunakan aturan yang jelas dan logis, (b) anak memiliki kecakapan berpikir logis terbatas pada benda yang bersifat konkrit. ${ }^{18}$ Jika pembelajaran dilakukan secara daring maka, untuk menciptakan suasana belajar dengan benda yang bersifat konkrit pada materi penjumlahan dan pengurangan dibutuhkan peran orang tua untuk mendampingi siswa supaya pembelajaran bermakna. Berdasarkan penjelasan tersebut pendampingan penyusunan media alat hitung manual (ALHIMA) kepada orang tua siswa kelas I SDN SUgihrejo I dan II menjadi penting untuk dilaksanakan.

\section{Persiapan}

Langkah awal yang dilakukan tim pengabdian kepada masyarakat (PKM) adalah memetakan masalah yang dihadapi oleh orang tua dalam mendampingi kegiatan belajar berhitung selama pemebelajaran daring di rumah. Orang tua kelas I SD dijadikan objek pendampingan karena mempertimbangkan usia siswa yang merupakan peralihan dari

18 C. Asri Budiningsih, Belajar Dan Pembelajaran (Jakarta: Rineka Cipta, 2015); Rangga Sa'adillah Sandhy Atma Putra, "Pembelajaran Pendidikan Agama Islam Melalui Pendekatan Saintifik Dalam Membentuk Sikap Spiritual Siswa Sekolah Menengah Atas Di Sidoarjo (Studi Fenomenologi Pengalaman Guru Dan Siswa Pada SMA Di Sidoarjo)" (Universitas Muhammadiyah Malang, 2020). 
Taman Kanak-kanak ke Sekolah Dasar, sehingga perlu kehadiran seorang pendidik untuk membimbing belajarnya. Namun situasi pandemi Covid-19 mengharuskan siswa belajar daring di rumah di dampingi orang tua. Selanjutnya tim PKM memberikan angket kepada 25 orang tua siswa kelas I di SDN Sugihrejo I dan SDN Sugihrejo II dengan hasil sebagai berikut:

Tabel 1. Hasil Angket Observasi Pendampingan Belajar Orang Tua

\begin{tabular}{llcc}
\hline \multirow{2}{*}{ No } & \multicolumn{1}{c}{ Pernyataan } & \multicolumn{2}{c}{ Jawaban } \\
\cline { 3 - 4 } & \multicolumn{1}{c}{ Ya } & Tidak \\
\hline 1 & Saya mendampingi anak belajar matematika & $100 \%$ & $0 \%$ \\
\hline 2 & $\begin{array}{l}\text { Saya mengalami kesulitan ketika mendampingi } \\
\text { anak belajar matematika }\end{array}$ & $76 \%$ & $24 \%$ \\
\hline 3 & $\begin{array}{l}\text { Anak saya mengalami kesulitan belajar } \\
\text { penjumlahan dan pengurangan }\end{array}$ & $76 \%$ & $24 \%$ \\
\hline 4 & $\begin{array}{l}\text { Anak saya bersemangat ketika saya dampingi } \\
\text { belajar penjumlahan dan pengurangan }\end{array}$ & $36 \%$ & $64 \%$ \\
\hline 5 & $\begin{array}{l}\text { Saya mengalami kesulitan ketika mendampingi } \\
\text { anak belajar penjumlahan dan pengurangan }\end{array}$ & $76 \%$ & $24 \%$ \\
\hline 6 & $\begin{array}{l}\text { Saya menggunakan media/alat ketika } \\
\text { mendampingi anak belajar berhitung }\end{array}$ & $0 \%$ & $100 \%$ \\
\hline 7 & $\begin{array}{l}\text { Saya membutuhkan pendampingan untuk } \\
\text { mendampingi anak belajar berhitung }\end{array}$ & $100 \%$ & $0 \%$ \\
\hline
\end{tabular}

Pada tabel 1. 76\% dari 25 orang tua siswa kelas I SDN Sugihrejo I dan SDN Sugihrejo II mengalami kesulitan dalam mendampingi siswa belajar berhitung. 100\% orang tua membutuhkan pelatihan untuk mendampingi anak belajar berhitung. Hal ini menunjukkan kesadaran orang tua terhadap pentingnya education parenting yang tinggi di Desa Sugihrejo. Pada dasarnya orang tua memiliki peranan penting dalam terciptanya kualitas pendidikan sebagaimana Menurut Winingsih (2020) terdapat empat peran orang tua selama Pembelajaran Jarak Jauh (PJJ) yaitu: 1. Berperan sebagai guru di rumah yaitu orang tua bertugas membimbing anaknya dari rumah selama PJJ 2. Berperan sebagai fasilitator yaitu orang tua menjadi sarana dan prasarana bagi anak selama PJJ. 3 . Berperan sebagai motivator yaitu orang tua memberikan semangat dan dukungan kepada anak dalam belajar, sehingga anak memiliki semangat belajar serta dapat berprestasi. 4. Orang tua sebagai pengaruh atau director. ${ }^{19}$

Selanjutnya tim PKM melakukan analisis kebutuhan melalui diskusi dengan orang tua terkait kesulitan orang tua dalam mendampingi belajar siswa pada materi berhitung.

19 Cahyati and Kusumah, "Peran Orang Tua Dalam Menerapkan Pembelajaran Di Rumah Saat Pandemi Covid 19." 
Adapun kesimpulan dari hasil diskusi adalah orang tua kelas I di Desa Sugihrejo membutuhkan pendampingan terkait penyusunan media alat hitung manual sebagai media dalam mendampingi anak belajar berhitung selama pembelajaran daring.

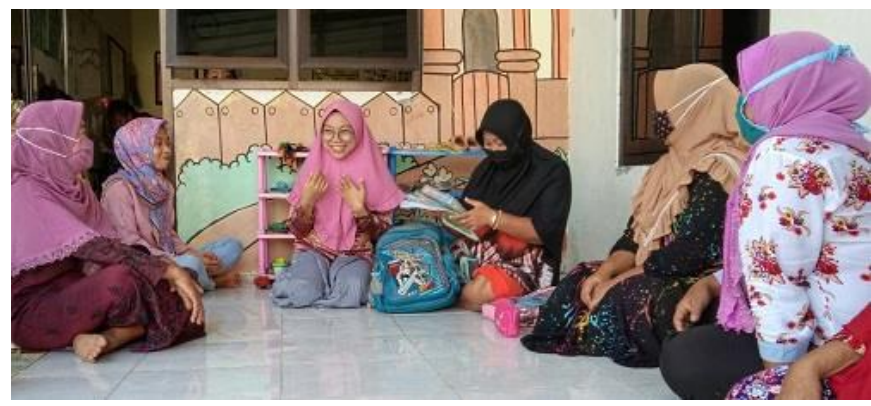

Gambar 3. Diskusi tim PKM dengan orang tua siswa Kelas I

Selanjutnya pada tahap ini Tim melakukan diskusi kepada guru dan Kepala sekolah SDN Sugihrejo I dan SDN Sugihrejo II untuk mendapatkan masukan yang membangun terhadap pelaksanaan pendampingan penyusunan alat hitung manual kepada orang tua siswa kelas I di Desa Sugihrejo. Dari diskusi tersebut diperoleh kesepakatan bahwa pihak sekolah sepenuhnya mendukung program pendampingan dan bersedia membantu mengkoordinasikan orang tua siswa untuk mengikuti pendampingan.

\section{Layanan}

Layanan diberikan orang tua siswa kelas I di desa Sugihrejo yang berjumlah 25 orang dari SDN Sugihrejo I dan SDN Sugihrejo II dalam menyusun alat hitung manual ini terbagi menjadi tiga kegiatan yaitu: (1) sosialisasi urgensi penggunaan media alat hitung manual; (2) pembuatan media alat hitung manual; dan (3) praktik penggunaan media alat hitung manual.

Pendampingan ini dilakukan secara berkelompok dengan membagi 25 orang tua menjadi 5 kelompok berdasarkan lokasi rumah. Adapun tahapan kegiatan adalah sebagai berikut:

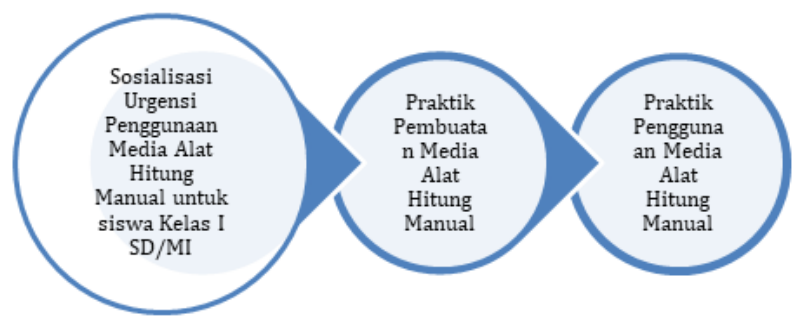

Gambar 4. Rincian Kegiatan pendampingan

Ilustrasi tahapan di atas mendeskripsikan rincian kegiatan yang dilakukan kepada lima kelompok orang tua di desa Sugihrejo. Kegiatan tersebut dilakukan selama lima hari 
antara tanggal 15 Agustus - 20 Agustus 2020. Pada kegiatan sosialisasi tim PKM menjelaskan pentingnya penggunaan media alat hitung manual untuk membantu siswa dalam memahami konsep penjumlahan dan pengurangan. Orang tua perlu menjadikan pembelajaran berhitung menjadi bermakna dalam artian, proses belajar tidak sekedar kegiatan menghafal konsep maupun fakta, akan tetapi belajar merupakan proses menghubungkan konsep-konsep supaya menjadi pemahaman yang utuh sehingga konsep yang dipelajari dapat dipahami dengan baik dan tidak mudah dilupakan. ${ }^{20}$ Setelah memperoleh sosialisasi urgensi penggunaan media, orang tua menjadi termotivasi untuk meningkatkan kualitas pendampingan belajar anak dengan menggunakan media pembelajaran.

Selanjutnya tim PKM memberikan pendampingan pembuatan media alat hitung manual dengan alat dan bahan sebagaimana berikut ini:

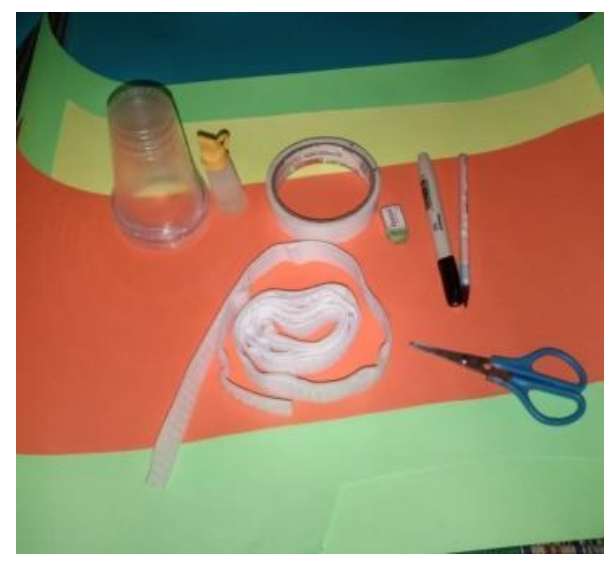

\section{Gambar 5. Alat dan Bahan Pembuatan Media ALHIMA}

Setelah alat dan bahan diberikan kepada masing-masing orang tua, kemudian tim PKM memberikan pendampingan pembuatan media alat hitung manual kepada setiap kelompok yang menghasilkan media alat hitung seperti pada gambar berikut:

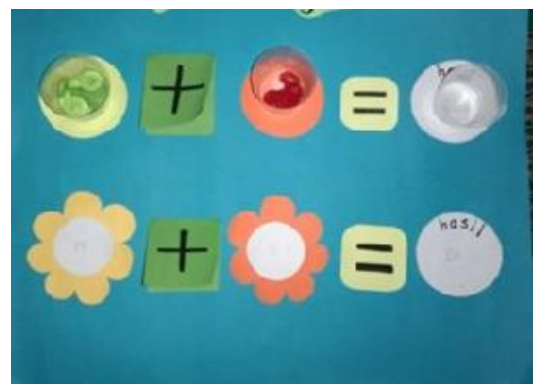

Gambar 6. Media Alat Hitung Manual (ALHIMA) 2019).

${ }^{20}$ Silviana Nur Faizah Ummu Khairiyah, Media Pembelajaran Tematik (Malang: Intelegensia Media, 


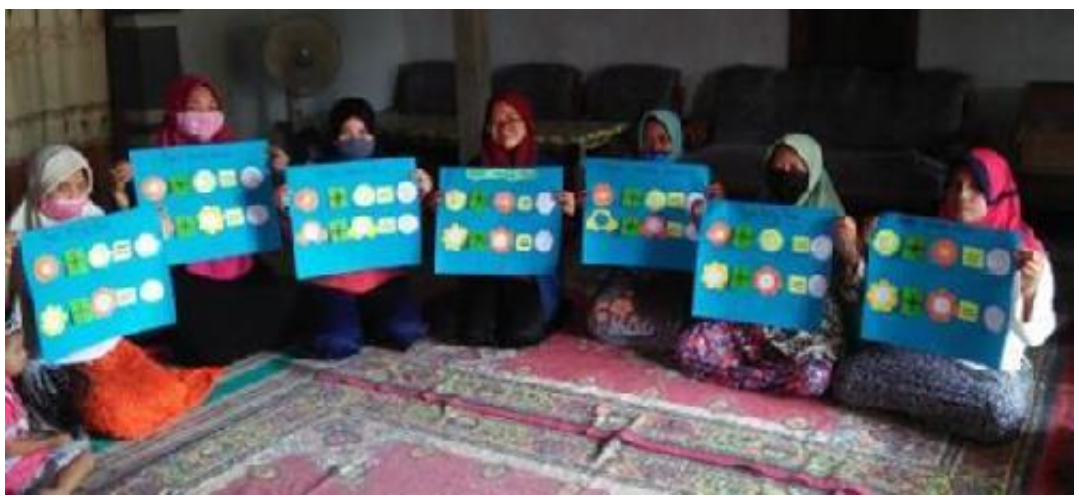

Gambar 7. Media ALHIMA Hasil Karya Orang Tua Siswa Kelas I Desa Sugihrejo

Setelah kegiatan pelatihan pembuatan media ALHIMA, orang tua siswa kelas I di Desa Sugihrejo secara mandiri dapat membuat media ALHIMA untuk mendukung proses pendampingan belajar berhitung. Selanjutnya tim PKM menjelaskan tata cara penggunaan media. Supaya tidak terjadi kesalahan dalam pemahaman konsep penjumlahan dan pengurangan, tim PKM mendampingi setiap orang tua hingga setiap orang tua paham dan dapat menggunakan media ALHIMA dengan benar.

\section{Refleksi}

Tahap akhir dari pendampingan ini yaitu refleksi yang dilakukan setelah masingmasing orang tua mendampingi anak belajar dengan menggunakan media ALHIMA. Berikut ini merupakan gambar kegiatan pendampingan belajar berhitung dengan menggunakan media ALHIMA:

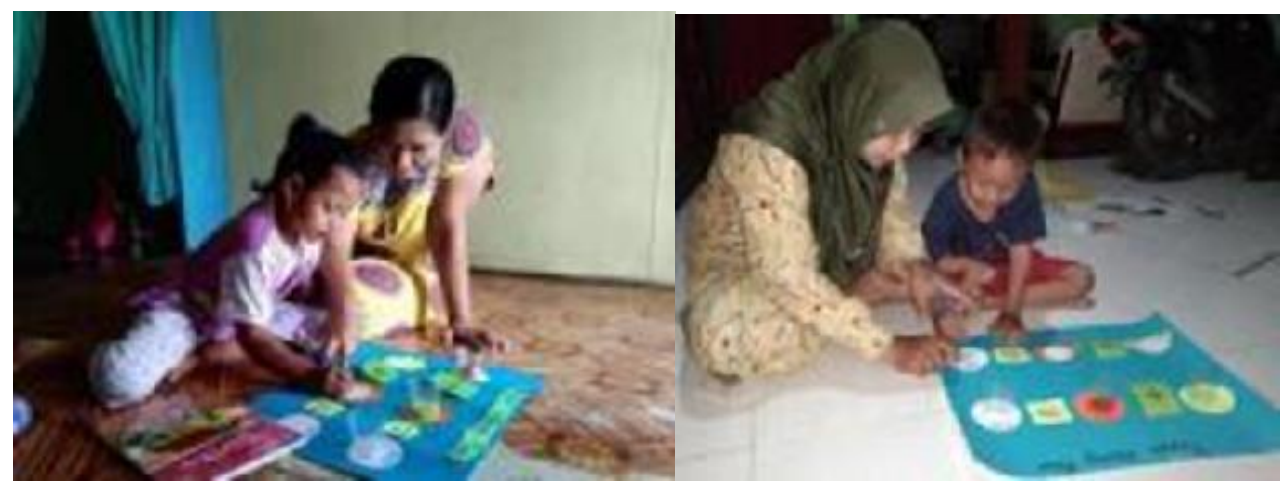

Gambar 8. Pendampingan belajar berhitung dengan media ALHIMA Orang tua siswa kelas I SDN Sugihrejo I dan II

Refleksi dilakukan dengan menggali data pemahaman materi pendampingan pembuatan media ALHIMA melalui angket yang diberikan kepada orang tua siswa. Adapun hasil angket adalah sebagai berikut: 
Tabel 3. Hasil Angket Pemahaman Pendampingan Penyusunan Media ALHIMA

\begin{tabular}{llcc}
\hline \multirow{2}{*}{ No } & \multicolumn{1}{c}{ Pernyataan } & \multicolumn{2}{c}{ Jawaban } \\
\cline { 2 - 4 } & \multicolumn{1}{c}{ Ya } & Tidak \\
\hline 1 & $\begin{array}{l}\text { Saya dapat mengungkapkan makna implementasi } \\
\text { konsep penjumlahan dan pengurangan }\end{array}$ & $100 \%$ & $0 \%$ \\
\hline 2 & $\begin{array}{l}\text { Saya dapat membuat media berhitung pada } \\
\text { materi penjumlahan dan pengurangan }\end{array}$ & $100 \%$ & $0 \%$ \\
\hline 3 & $\begin{array}{l}\text { Saya dapat menggunakan media berhitung untuk } \\
\text { mendampingi anak belajar penjumlahan dan } \\
\text { pengurangan }\end{array}$ & $100 \%$ & $0 \%$ \\
\hline 4 & $\begin{array}{l}\text { Anak saya merasa tertarik belajar penjumlahan } \\
\text { dan pengurangan dengan media hitung yang saya } \\
\text { gunakan }\end{array}$ & $100 \%$ & $0 \%$ \\
\hline 5 & $\begin{array}{l}\text { Anak saya dapat memahami konsep penjumlahan } \\
\text { dan pengurangan setelah menggunakan media } \\
\text { hitung }\end{array}$ & $100 \%$ & $0 \%$ \\
\hline
\end{tabular}

Pada tabel 3 menunjukkan bahwa pendampingan penyusunan media ALHIMA kepada orang tua siswa kelas I di desa Sugihrejo memberikan dampak yang signifikan terhadap pengetahuan dan keterampilan orang tua dalam mendampingi anak belajar berhitung. Dalam hal ini seluruh orang tua siswa kelas I di desa Sugihrejo dapat menciptakan suasana belajar yang menarik perhatian siswa sehingga siswa dapat memahami konsep penjumlahan dan pengurangan dengan baik.

\section{Diskusi}

Hasil angket pemahaman pendampingan sebagaimana tabel 3 menggambarkan bahwa pelaksanaan pendampingan penyusunan media ALHIMA dapat memberikan solusi yang tepat terhadap masalah pendampingan belajar berhitung yang dialami oleh orang tua siswa kelas I SD di Desa Sugihrejo. Adapun dampak dilaksanakannya pendampingan penyusunan media ALHIMA terhadap orang tua siswa diantaranya: (1) orang tua mengetahui pentingnya penggunaan media pembelajaran dalam mendampingi anak; (2) orang tua mengetahui konsep penjumlahan dan pengurangan; dan (3) orang tua semakin sadar akan pentingnya memberikan pengasuhan/pendampingan terbaik untuk mewujudkan keberhasilan akademis anak. Keberhasilan pelaksanaan pendampingan tidak lepas dari peran aktif dan komunikatif orang tua selama proses pendampingan yangmana, berdasarkan konsep participatory learning menegaskan bahwa belajar merupakan proses aktif pembelajar, dimana pembelajar memperoleh pengetahuan tidak hanya dari pengajarnya tapi juga melalui pengalaman saat belajar. ${ }^{21}$

21 Purwati Purwati et al., "Peningkatan Pengetahuan Dan Keterampilan Orang Tua Untuk Mencegah Bullying Guna Mewujudkan Desa Layak Anak," CARADDE: Jurnal Pengabdian Kepada Masyarakat 
Kemampuan orang tua dalam menggunakan media ALHIMA dalam mendampingi anak belajar, mampu menciptakan suasana belajar yang menarik perhatian, sehingga dalam hal ini siswa dapat memahami konsep penjumlahan dan pengurangan dengan baik karena media ini memberikan pengalaman nyata kepada siswa untuk mengoperasikan penjumlahan dan pengurangan. Menurut Edgar Dale Direct Purposeful Experiences (Pengalaman Langsung) penting untuk diberikan karena pada dasarnya otak manusia belum mampu melakukan penggambaran secara abstrak sehingga membutuhkan interaksi seluruh indra yang dimiliki manusia baik melihat, mendengar, memegang, merasakan, menyentuh dan lainnya. ${ }^{22}$ Selain itu penggunaan media ALHIMA ini memperhatikan tahapan perkembangan berpikir siswa sesuai dengan teori Piaget bahwa untuk mengoperasikan konsep penjumlahan anak SD memerlukan penggunaan bendabenda nyata, terutama di kelas-kelas awal karena tahap perkembangan berfikir mereka baru mencapai pada tahap konkret. ${ }^{23}$

Berdasarkan hasil pelaksanaan pendampingan penyusunan media ALHIMA yang dilakukan oleh tim PKM yang terdiri dari dosen dan mahasiswa Pendidikan Guru Madrasah Ibtidaiyah Universitas Islam Lamongan disimpulkan bahwa dengan dilaksanakannya program service learning di tengah pandemi Covid-19 merupakan bentuk pelayanan untuk membantu orang tua siswa menghadapi permasalahan dalam pendampingan belajar selama pembelajaran daring di Sugihrejo. Kegiatan pengabdian ini merupakan cerminan manfaat akademis yang diberikan oleh perguruan tinggi dan pendidikan guru pada khususnya sebagaimana pendapat Patterson Daniels and Dunston yang menyatakan bahwa perguruan tinggi dan Pendidikan guru hendaknya memiliki manfaat akademis yang melibatkan masyarakat dalam bentuk mempengaruhi tindakan individu maupun kelompok untuk mengidentifikasi dan mengatasi masalah yang menjadi perhatian publik, dan memahami hubungan antara program pengabdian masyarakt dan dampaknya terhadap infrastruktur sosial dan budaya masyarakat. ${ }^{24}$

Selain itu kegiatan ini sesuai dengan filosofi belajar di luar dari program service learning yaitu mahasiswa selain mampu memahami materi dan nilai-nilai yang diperoleh selama perkuliahan, mahasiswa juga menerapkan materi tersebut untuk memberikan nilai tambah pada orang lain dengan melakukan kegiatan melayani orang lain pada masyarakat. ${ }^{25}$

\footnotetext{
1, no. 2 (2019): 228-233.

22 Ummu Khairiyah, Media Pembelajaran Tematik.

23 Jean Piaget dan Barbel Inhelder, The Psychology of Child Terjemahan Miftahul Jannah (Yogyakarta: Pustaka Belajar, 2010).

24 Thuwayba Al Barwani and Abdo Al-mekhlafi, "Service-Learning Might Be the Key: Learning From the Challenges and Implementation Strategies in EFL Teacher Education in Oman," International journal of instruction 6, no. 2 (2013): 109-127.

25 Irene Nusanti, "Strategi Service Learning Sebuah Kajian Untuk Mengembangkan Kegiatan Pembelajaran," Jurnal Pendidikan dan Kebudayaan 20, no. 2 (2014): 251.
} 


\section{Kesimpulan}

Program pengabdian kepada masyarakat melalui pendampingan penyusunan media alat hitung manual yang dilaksanakan di tengah pandemic Covid-19 merupakan solusi yang tepat untuk mengatasi permasalahan yang dihadapi oleh orang tua dalam mendampingi belajar berhitung siswa kelas I di Desa Sugihrejo selama dilaksanakannya pembelajaran daring. Pada pendampingan ini terdapat tiga kegiatan inti yang diberikan kepada orang tua siswa: (1) sosialisasi urgensi penggunaan media alat hitung manual untuk anak kelas I SD/MI; (2) pembuatan media alat hitung manual; dan (3) praktik penggunaan media alat hitung manual. Dalam rangka memecahkan masalah kesulitan orang tua dalam pendampingan belajar materi berhitung, dilaksanakannya program pengabdian ini terbukti dapat memperbaiki kualitas pendampingan belajar orang tua pada materi berhitung yang ditandai dengan keterampilan baru yang dimiliki orang tua diantaranya: (1) mengetahui pentingnya penggunaan media pembelajaran; (2) menguasai konsep penjumlahan dan pengurangan; (3) menggunakan media ALHIMA untuk pendampingan belajar materi berhitung; dan (4) sadar pentingnya memberikan pendampingan terbaik untuk keberhasilan akademis anak. Berdasarkan hasil program pendampingan ini maka dapat direkomendasikan sebagai berikut: (1) perlu adanya rancangan model pendampingan penyusunan media alat hitung manual kepada seluruh orang tua untuk mewujudkan tuntas berhitung di kelas rendah; (2) perlu adanya kolaborasi perguruan tinggi, Sekolah Dasar/Madrasah Ibtidaiyah, dan stakeholders untuk meningkatkan partisipasi orang tua dalam mengasuh/mendampingi kegiatan belajar anak untuk meningkatkan kualitas pendidikan.

\section{Pengakuan}

Diucapkan terima kasih sebesar-sebesarnya kepada pihak-pihak yang terlibat dalam kegiatan pengabdian kepada masyarakat yaitu Pusat Penelitian dan Pengabdian Masyarakat (Litbangpemas) Universitas Islam Lamongan, Kepala Sekolah dan Guru Kelas I SDN I dan II di Desa Sugihrejo, dan Orang tua siswa kelas I di Desa Sugihrejo. Tim PkM mengucapkan terimakasih atas partisipasi aktif dari semua pihak sehingga program pengabadian ini dapat berjalan sesuai dengan tujuan. 


\section{Daftar Referensi}

Abdul Rasyid Tolangara, and Rohima Wahyu Ningrum. "Pendampingan Komunitas Sekolah Melalui Kegiatan Vertical Garden Untuk Mewujudkan Sekolah Dasar Berbasis Lingkungan Di SDN 34 Kota Ternate Maluku Utara." Engagement: Jurnal Pengabdian Kepada Masyarakat 2, no. 1 (2018): 62-70.

Abdul Rasyid Tolangara, and Rohima Wahyu Ningrum. "Pendampingan Komunitas Sekolah Melalui Kegiatan Vertical Garden Untuk Mewujudkan Sekolah Dasar Berbasis Lingkungan Di SDN 34 Kota Ternate Maluku Utara." Engagement: Jurnal Pengabdian Kepada Masyarakat 2, no. 1 (2018): 62-70.

Akhyadi, Ade Sadikin, and Dinno Mulyono. "PROGRAM PARENTING DALAM MENINGKATKAN KUALITAS PENDIDIKAN KELUARGA (Program Pengabdian Di Desa Karangpakuan, Kecamatan Darmaraja, Kabupaten Sumedang)." Abdimas, IKIP SILIWANGI 1, no. 1 (2018): 1-8.

Akmal, Sari Zakiah, Tjut Rifameutia Ali-nafis, and Patricia Adam. "Efektifitas Program Pelatihan Orang Tua Untuk Meningkatkan Motivasi Menulis Pada Siswa Lambat Belajar." Jurnal Psikogenesis 2, no. 1 (2013): 1-13.

Ariyanti, Ariyanti, and Zidni Muslimin. "Efektivitas Alat Permainan Edukatif (APE) Berbasis Media Dalam Meningkatkan Kemampuan Berhitung Pada Anak Kelas 2 Di SDN 2 Wonotirto Bulu Temanggung." Jurnal Psikologi Tabularasa 10, no. 1 (2015): 58-69.

Barwani, Thuwayba Al, and Abdo Al-mekhlafi. "Service-Learning Might Be the Key: Learning From the Challenges and Implementation Strategies in EFL Teacher Education in Oman." International journal of instruction 6, no. 2 (2013): 109-127.

Budiningsih, C. Asri. Belajar Dan Pembelajaran. Jakarta: Rineka Cipta, 2015.

Cahyati, Nika, and Rita Kusumah. "Peran Orang Tua Dalam Menerapkan Pembelajaran Di Rumah Saat Pandemi Covid 19." Jurnal Golden Age, Universitas Hamzanwadi 04, no. 1 (2020): 4-6.

Đurišić, Maša, and Mila Bunijevac. "Parental Involvement as a Important Factor for Successful Education.” Center for Educational Policy Studies Journal 7, no. 3 (2017): 137-153.

Heri Setiawan. "Peran Orang Tua Dalam Pembelajaran Daring." Suara Merdeka. Indonesia, 2020.

Inhelder, Jean Piaget dan Barbel. The Psychology of Child Terjemahan Miftahul Jannah. Yogyakarta: Pustaka Belajar, 2010.

Menteri Pendidikan dan Kebudayaan Republik Indonesia. PELAKSANAAN KEBIJAKAN PENDIDIKAN DALAM MASA DARURAT PENYEBARAN CO RO NAVIRU S D/SEASE (COVID- 19 ). Indonesia, 2020. 
Mulyasa. Manajemen Dan Kepemimpinan Kepala Sekolah. Jakarta: Grafika Offset, 2011.

Nazarudin, Mgs. "Pola Kerjasama Guru Dan Orang Tua Dalam Meningkatkan Mutu Pendidikan Di MIN 2 Kota Palembang." Intizar 24, no. 2 (2018): 9-16.

Nusanti, Irene. "Strategi Service Learning Sebuah Kajian Untuk Mengembangkan Kegiatan Pembelajaran." Jurnal Pendidikan dan Kebudayaan 20, no. 2 (2014): 251.

Purwati, Purwati, Muhammad Japar, Septi Wardani, and Rohmayanti Rohmayanti. "Peningkatan Pengetahuan Dan Keterampilan Orang Tua Untuk Mencegah Bullying Guna Mewujudkan Desa Layak Anak." CARADDE: Jurnal Pengabdian Kepada Masyarakat 1, no. 2 (2019): 228-233.

Putra, Rangga Sa'adillah Sandhy Atma. “Pembelajaran Pendidikan Agama Islam Melalui Pendekatan Saintifik Dalam Membentuk Sikap Spiritual Siswa Sekolah Menengah Atas Di Sidoarjo (Studi Fenomenologi Pengalaman Guru Dan Siswa Pada SMA Di Sidoarjo)." Universitas Muhammadiyah Malang, 2020.

Reimers, Fernando, Andreas Schleicher, Jaime Saavedra, and Saku Tuominen. "Supporting the Continuation of Teaching and Learning during the COVID-19 Pandemic" (2020): 1-38.

Setyowati, Endah, and Alviani Permata. "Service Learning: Mengintegrasikan Tujuan Akademik Dan Pendidikan Karakter Peserta Didik Melalui Pengabdian Kepada Masyarakat." Bakti Budaya 1, no. 2 (2018): 143.

St. Syamsudduha, St. Syamsudduha, and Nurjannah Yunus Tekeng. "Penerapan Service Learning Dalam Pembelajaran Matakuliah Pedagogik Pada Kurikulum Pendidikan Calon Guru." Lentera Pendidikan: Jurnal Ilmu Tarbiyah dan Keguruan 20, no. 1 (2017): 1-17.

Umiarso dan Imam Gojali. Manajemen Mutu Sekolah Di Era Otonomi Pendidikan. Jogjakarta: IRCiSod, 2011.

Ummu Khairiyah, Silviana Nur Faizah. Media Pembelajaran Tematik. Malang: Intelegensia Media, 2019.

Venessa Damons, Helen Dunbar-Krige. "The Use of Reflection in a Service-Learning Project in a Post-Graduate Programme." Journal of Service-Learning in Higher Education 53, no. 9 (2019): 1689-1699.

Wajdi, Muh Barid Nizarudin, Iwan Kuswandi, Umar Al Faruq, Zulhijra Zulhijra, Khairudin Khairudin, and Khoiriyah Khoiriyah. "Education Policy Overcome Coronavirus, A Study of Indonesians." EDUTEC: Journal of Education And Technology 3, no. 2 (2020): 96-106.

Wajdi, Muh Barid Nizarudin, M Burhanuddin Ubaidillah, Sri Mulyani, Khoirul Anwar, Lailatul Istiqomah, Fauziyah Rahmawati, Sholihatul Atik Hikmawati, Diah Retno Ningsih, and Hasan Syaiful Rizal. "Pendampingan Redesign Pembelajaran Masa 
Pandemi Covid-19 Bagi Tenaga Pendidik Di Lembaga Pendidikan Berbasis Pesantren Di Jawa Timur." Engagement: Jurnal Pengabdian Kepada Masyarakat 4, no. 1 (2020): 266-277.

Yulia, Henny. "Online Learning to Prevent the Spread of Pandemic Corona Virus in Indonesia." ETERNAL (English Teaching Journal) 11, no. 1 (2020): 48-56. 